\title{
14 \\ VETERANS AND THE POLITICS OF CITIZENSHIP
}

\author{
Lia Kent
}

Symbols of veteran identity are everywhere in Timor-Leste. National heroes and the major turning points in the 24-year resistance struggle are celebrated in monuments and public holidays. The remains of hundreds of deceased members of the Armed Forces for the National Liberation of East Timor (Forças Armadas da Libertação Nacional de Timor-Leste - FALINTIL) combatants rest in a Garden of Heroes cemetery in Metinaro. Perhaps of most consequence, however, is the requirement in Timor-Leste's constitution that the state 'valorise' the resistance by 'protect[ing] those who participated in the resistance against foreign occupation' and their dependents (RDTL 2002: s11.3), and develop[ing] mechanisms for 'rendering tribute' to national heroes (s11.4). 'Rendering tribute' includes the bestowal of medals and special uniforms, but is made most tangible through the provision of pensions to those who can successfully claim veteran status. Payments to veterans now consume a significant and growing percentage of the state budget (7.5\% was allocated in 2017) and more is now spent on veterans than health (La'o Hamutuk 2017). ${ }^{1}$ These payments are likely to continue until 2,122 and cost an estimated $\$ 2.8$ billion dollars (La'o Hamutuk 2013). ${ }^{2}$

In a context where a significant percentage of the population lives below the poverty line, there is much at stake in successfully claiming veteran status. In addition to becoming eligible for sizeable pensions, veterans are granted preferential access to government contracts (La'o Hamutuk 2013) ${ }^{3}$ and veterans' views, not surprisingly, carry weight in parliamentary debates, election campaigns, and in local politics. ${ }^{4}$ These high stakes are reflected in the number of Timorese who have sought to register their names in order to be assessed for a veterans' pension. There are now 200,755 names in the database. ${ }^{5}$ As several commentators point out, this figure seems unrealistically high given that Timor-Leste has a population of around one million people and more than half of them are too young to have participated in the resistance struggle (Myrttinnen 2014: 99-100; Rothschild 2015).

Against this backdrop, it is not surprising that public criticism has emerged, focusing on the lack of financial sustainability of veterans' payments in the context of declining oil and gas revenues from the Timor Sea (La'o Hamutuk 2013; Fundasaun Mahein 2015). A further set of critiques is beginning to shed light on the ways veterans' programmes contribute to shaping the boundaries of inclusion and exclusion within current imaginings of the nation (see in particular Roll 2014a, 2014b). This latter set of critiques is informed by the insights of critical peacebuilding scholars who have explored, in a range of contexts, the intricate ways in which 
disarmament, demobilisation and reintegration (DDR) programmes and longer term veterans' support programmes are entangled with broader questions of political economy, state formation and the constitution of identities (e.g. Pouligny 2004; Sriram and Herman 2009; Wale 2016). Rather than treating these programmes as ostensibly 'technical' exercises that simply recognise pre-existing identities (as much of the policy literature tends to do), this scholarship is interested in how the practices and discourses of these programmes actively constitute identities and embed them in the fabric of social life. It examines how, by this process, insiders and outsiders and hierarchies of the deserving are constructed in ways that have long-term ramifications for questions of citizenship and inequality (Wale 2016: 34).

This chapter provides an overview of key themes emerging from recent scholarship on veterans and the nation-building process in Timor-Leste. It brings these themes into dialogue with recent insights from the critical citizenship literature to argue that veterans' programmes have emerged as a key site at which 'hierarchies of citizenship' (Martins 2017: 100) are both constructed and negotiated. I adopt a dynamic conceptualisation of citizenship that moves beyond an exclusive preoccupation with citizenship as a legal and political category that is bestowed (or denied) by the state. I aim to be alert to the 'social, political, cultural and symbolic practices of making citizens' (Isin 2008: 17) and to the ways in which citizenship is enacted, performed or asserted through everyday mechanisms and actions (Jeffrey and Jakala 2015: 44). By attending to how social policies and practices 'shape people's attitudes, behaviour and aspirations' about the meanings of citizenship and to the interpretations and strategies that citizens adopt in relation to those policies and practices (Ong 2003: 27-28), individuals are not treated as passive recipients of a predetermined concept. Rather, they are seen as being active in the construction of their own citizenship, even as they are also constrained by broader social and political structures and discourses (McEwen 2005: 972). This more dynamic understanding of citizenship, as shall become evident, is a useful starting point for considering how the veterans' scheme in Timor-Leste shapes attitudes about, and yet is never fully able to settle, the question of whose lives are most valued in the national imagination.

After an overview of some of the powerful imperatives that appear to underpin the political elite's preoccupation with veterans' issues, the chapter traces the evolution of programmes to deal with these issues in Timor-Leste. I highlight how these programmes contribute to the emergence of the veteran as a prominent identity category and elevate the status of elite, male combatants. At the same time, they reveal the 'veteran' to be a fundamentally unsettled notion. I then show how the labile nature of veteran identity is also evident in the ongoing attempts to 'resolve' what has been termed the veterans' question (kestaun veteranus) through processes of 'verification.' The following section draws on Kate Roll's compelling on-the-ground observations of the verification process to demonstrate how the 'gatekeeping' practices of commissioners have made veteran status an increasingly negotiated commodity (Roll 2014a: 96). Finally, I explain how the negotiated dimension of the scheme has opened up possibilities of struggles for recognition by other diverse groups in society whilst also limiting the parameters of the debate.

\section{Valorisation and security imperatives}

The size of the veterans' pension scheme and the preoccupation with veterans' issues generally in Timor-Leste needs to be understood in the context of two powerful imperatives: valorisation and national security. The constitutionally embedded imperative to 'valorise' heroes is driven by a powerful nationalist narrative of resistance that, since the nation's independence, has been central to the political elite's efforts to 'imagine' a post-conflict national identity and

186 


\section{Veterans and politics}

bolster the legitimacy of the state (Leach 2017: 167-68). This narrative celebrates the story of how the East Timorese, through courage, forbearance, national unity and sacrifice, overcame successive colonial occupiers to achieve the nation's independence. Its prominence is of a piece with the fact that in Timor-Leste, as in many postcolonial nations that emerged from liberation struggles, the political landscape remains dominated by figures who played key roles in the struggle for independence long after the struggle ended (Myrttinen 2014: 99).

Because it resonates amongst much of the population, the resistance narrative appears at face value to be a unifying and nation-building force (Leach 2017: 164). Yet, beneath its broadly unifying veneer, complex and shifting debates continue to take place about which political party or group is entitled symbolically to 'own' it (Leach 2017: 164). Moreover, the resistance narrative is inevitably both exclusionary and reductive. It is exclusionary in the sense that, by reifying certain historical experiences and subject positions (namely that of the male resistance fighter), it delineates those who have a legitimate place in the nation (and those who do not). It is reductive in the sense that it works to mask the complexities of the resistance struggle - including its internal divisions and the blurred (rather than sharp) lines between the roles of combatant, civilian and collaborator. That this masking is deemed necessary in the first place speaks volumes about postcolonial anxieties around the fragility of national unity.

Intricately entwined with the valorisation imperative, anxieties about questions of national security have also informed the preoccupation with veterans' issues. Security is an underpinning rationale of DDR and long-term veterans support programmes which, at the time of the UN Transitional Administration in East Timor (UNTAET) state-building intervention, had become central to post-conflict peacebuilding orthodoxies (Muggah and O'Donnell 2015: 2). A key concern is that, without assisting ex-combatants to reintegrate into society, this group will remain a 'ticking time bomb' and a destabilising influence (de Vries and Wiegink 2011: 38). Security anxieties were an understandable preoccupation during the transition to national independence, and resurfaced once more during the 2006 crisis, which saw the mobilisation of several groups of disaffected veterans, and the growing visibility of a number of resistance era fault lines (Myrttinen 2014: 95). These anxieties mean that East Timorese veterans are not only designated as heroes of the nation, but they are also deemed to be potential 'spoilers' with the capacity to destabilise the self-same nation. This dual construction of the veteran as hero and social problem poses obstacles to the reduction of veterans' benefits and justifies the targeting of veterans disproportionately over other groups in society (cf Metsola 2006: 1128).

At a more concrete level, the current veterans' pension scheme is an outcome of the various veterans' assistance and registration programmes established by the international community and the East Timorese government following the referendum. These programmes have, over time, worked to shore up the interests of elite, male, former combatants over those who played different kinds of roles during the resistance. Nonetheless, the attempts of these programmes to definitively settle the question of who and who is not a veteran have similarly proved elusive. In part, this is because, as the political, economic and symbolic stakes associated with this form of identity have grown, so too have the number of individuals seeking to lay a claim to it.

\section{The evolution of the veterans' pension scheme and of armed male combatants}

The first programme to address veterans' issues was initiated by UNTAET in the aftermath of the 1999 referendum. UNTAET had a mandate not only to deal with immediate DDR priorities but also to assist former combatants to make the transition to civilian life 
(Kings College London 2003: para 48). A particular preoccupation was what to do with a group of around 1,950 former FALINTIL fighters who were gathered together in a cantonment in Aileu. Despite its mandate, UNTAET was very slow to act, in part because UN rules proscribed it from providing assistance to armed groups, and because no decision had yet been reached about whether and how a national military force might be established (World Bank 2008: 7; Kings College London 2003 para v). After much deliberation between UNTAET and the Timorese leadership, 15 months after their initial cantonment, 650 former guerrillas were selected by Xanana Gusmão and the FALINTIL high command to join the new national defence force (ICG 2011: 4). The remaining 1,300 were channelled into the FALINTIL Reinsertion Assistance Programme (FRAP) that was funded by the World Bank and the US Agency for International Development (USAID), and implemented by the International Organization for Migration (IOM). The objective of FRAP was to assist the social and economic reintegration of former combatants through a year-long programme that provided tools, training and grants to begin income-generating activities (Kent 2006).

A key limitation of FRAP was its conceptualisation as a short-term response that aimed to diffuse what was perceived to be an immediate security threat - combatants in the cantonment. The programme, in other words, failed to address long-term questions of reintegration. Moreover, in the process of diffusing one threat, FRAP created a new set of issues. For instance, the role played by Xanana Gusmão and the FALINTIL high command in deciding which former combatants would be selected to join the new national defence force (without reference to well-publicised selection criteria), fostered resentments amongst those who missed out (World Bank 2008: 8; ICG 2011: 4). FRAP also excluded those who had left the cantonment before the programme had begun as well as those who had participated in FALINTIL in the earlier years of the conflict (and had left by the time of the referendum). These resentments fuelled the emergence of a number of 'ex-FALINTIL' veterans' groups, which were construed as potential threats to security in the post-independence period (World Bank 2008: 8; ICG 2011).

Since FRAP, responsibility for dealing with veterans' issues has largely fallen to the newly independent Timor-Leste state. These efforts began in August 2002, when then President Xanana Gusmão established two veterans' commissions with a remit to identify and register veterans of the armed front. The Commission for the Issues of Former Combatants (Comissão para os Assuntos dos Antigos Combatentes - CAAC) and the Commission for the Issues of FALINTIL Veterans (Comissão para os Assuntos dos Veteranos do FALINTIL - CAVF) were tasked jointly with registering combatants who had participated in the struggle from 1975 to 1999. Together, they recorded the names of approximately 36,959 individuals (Kent 2006: 12).

The focus on the armed front brought another set of issues to the fore, however, as members of the clandestine front - the network of thousands of Timorese men and women based in the villages and towns who had provided critical support to FALINTIL - felt themselves to be unfairly excluded (Kent 2006: 12). The response of Gusmão was to establish another commission, the Commission for Matters of Cadres of the Resistance (Comissão para os Assuntos dos Quadros da Resistência - CAQR), in 2004, which registered cadres who had held formal positions within the civilian ranks of the resistance (otherwise known as the clandestine front). The CAQR registered 36,606 individuals, including 9,796 women (or $27 \%$ of registrants.)

Following these initial registration attempts, veterans' debates shifted to the realm of legislation development and informed the drafting of the 2006 Statute of the National Liberation Combatants. The statute defined a 'National Liberation Combatant' (NLC) as a Timorese citizen who participated in the independence struggle for more than three years (or less than

188

Routledge Handbook of Contemporary Timor-Leste, edited by Andrew McWilliam, and Michael Leach, Taylor \& Francis Group, 2019. ProQuest Ebook Central, http://ebookcentral.proquest.com/lib/anu/detail.action?docID=5735471. Created from anu on 2020-06-08 19:13:05. 


\section{Veterans and politics}

three years if killed due to their participation in the struggle) and was 'part of the structures or organizations of the Resistance. ${ }^{\prime 6}$ It outlined that benefits for NLCs would include various forms of symbolic recognition, including medals, the right to funeral honours, and presidential decorations. ${ }^{7}$ NLCs, their spouses and children were also granted rights to access state health and education services free of charge. ${ }^{8}$ A later decree established scholarships to assist with uniforms, books and tertiary education fees for veterans' children. ${ }^{9}$ The legislation also provided entitlements to pensions for certain veterans.

Whilst the 2006 statute was an attempt to fix the definition of veteran-hood (and the rights that would be extended to different veterans), this attempt proved elusive. Since its enactment, parliament has made various amendments to the veterans' legislation, in particular to pension requirements. A key change has involved a shift from an emphasis on 'vulnerability' to a focus on 'length of service' and 'rank' in the resistance hierarchy as key factors in determining pension amounts. ${ }^{10}$ A combatant's years of service are considered to be the sum of all periods of deportation, detention and work in 'exclusive dedication' to the Resistance ('exclusive dedication' meaning that individuals were not engaged in study or regular waged labour). Pension amounts have also risen steadily. Whilst the lowest pension to living former resistance members was initially USD 85 per month, this has now grown to USD 276 per month, an amount that is many times higher than the average monthly Timorese income (Kent and Wallis 2014). ${ }^{11}$ At the other end of the spectrum, the 'superior pension,' which is designated for a tiny group of 15 individuals who played prominent roles in the liberation struggle, provides USD750 per month. This is, as Roll (2014a: 105) points out, 'more than double the average yearly income.'

These shifts in the veteran's scheme appear to reflect a confluence of factors and influences, amongst them, political pressure from powerful former guerrillas promoting the valorisation imperative (who have close personal connections to Xanana Gusmão) and newly flowing oil revenues and security anxieties in the wake of the 2006-2007 crisis. The effect of these shifts has been the development of a scheme that is narrowly associated with those who participated in the armed component of the resistance struggle, to the detriment of those who participated in the clandestine front (Kent and Kinsella 2015). The requirement to prove 'exclusive dedication' to the resistance for more than three years has made it difficult for members of the clandestine front (who often concealed their activities behind study or work, or used their position within the Indonesian government, police or military to pass on intelligence to the resistance) to make up the required years. ${ }^{12}$

Women, who often supported the resistance in informal ways rather than holding designated ranks within formal resistance structures, have been particularly marginalised within the veterans' scheme. By elevating questions of rank, length of service, uniforms and weapons, the scheme has promoted a narrative in which men are 'the real actors' and women are accorded support roles as cooks, couriers, messengers and carers of children (Nagel 1998: 244). Only a small number of women have been able to live up to the militarised, masculine ideals enshrined in the veterans' scheme. After much lobbying, a small group of women who had been stationed with FALINTIL in the jungle for the duration of the resistance were, in 2006, granted the symbolic 'Order of the Guerilla. ${ }^{13}$ However, there is a sense that, even for this group, the recognition was given grudgingly (Niner 2013: 242).

\section{Resolving the kestaun veteranus (veterans question)}

Anxieties about veterans' issues have carried over into the various processes designed to 'verify' veterans' claims and are present in public debates about how best to resolve what has been termed the kestaun veteranus (veterans' question) (ICG 2011: 6). This 'question' is not always 
clearly defined (ICG 2011: 6) but, in a general sense, it revolves around a perception that the registration data have yet to be accurately verified. This situation, in turn, is construed as a failure of the state to fulfil the valorisation imperative by adequately repaying those who struggled and sacrificed for the nation (see Kammen 2009: 387-391; ICG 2011: 6). An added dimension of the veterans' question is a public anxiety that so-called 'false veterans (veteranus falsu) are unfairly benefitting from the scheme at the expense of 'authentic' applicants. There are frequent complaints that individuals have exaggerated their service or have been under-recognised for their years of active engagement, and calls for the reactivation of resistance structures in order to weed out the false claims from the authentic (e.g. Gusmão 2016a).

Part of the reason for these anxieties is that, due to the high stakes associated with veteran identity, the number of those claiming veteran status has increased significantly over the past few years. A notable surge occurred in 2009 when, in the wake of the 2006 crisis, the then new Prime Minister Gusmão - in a pragmatic recognition of the need to 'buy peace' - opened a new round of registration. Around 125,000 self-identified former resistance members registered as veterans at this time, adding to the 76,000 names already in the database. The data set of those who registered in 2009 has yet to be verified by the body currently entrusted with this role, namely, the Commission for Homage, Supervision of Registration, and Appeals (Comissão de Homenagem, Supervisão do Registo e Recursos - CHSRR).

The CHSRR (organised into 65 councils composed of local resistance leaders) is tasked with supervising the public display of registration lists and holding community-level meetings during which there is an opportunity for individuals to make complaints regarding errors or the improper inclusion of names (Roll 2014a: 96). Yet, verifying veterans' claims has proven incredibly complex. Aside from the fact that there are so many claims to deal with, there are political issues associated with completing the verification of data from the earlier phase of registration and moving on to the 2009 data set. In particular, there remain around 5,000 complaints requiring resolution, primarily involving individuals seeking to register an increase in their years of participation in the resistance, and hence their pension amounts. Given that there is no limit on the number of complaints an individual can make (and there is pressure from sections of the military to resolve all complaints before moving on to the 2009 data set), it seems unlikely that those who registered in 2009 will have their claims assessed for some time to come. ${ }^{14}$

Adding to these complexities is the fact that the CHSRR is confronted with the 'potentially unresolvable' challenge of 'seeking to represent a 'complex history in administrative categories' (Roll 2014a: 87). The very messiness of the Indonesian occupation confounds attempts to draw clear lines between those 'in' and 'out' (Roll 2014a: 87). For one thing, the structures of the resistance were nowhere near as defined as clear-cut as the ranks listed in the veteran registration form suggest. The registration form lists neat chains of command, and titles which are more fictive than a reflection of reality (Roll 2014a: 70). It also rests on a clean division between the armed, clandestine and diplomatic fronts which was often blurred in practice. Furthermore, the veterans' scheme's attempt to draw bright lines between 'resistance' and 'collaboration' is fraught in a context where, during the Indonesian occupation, many East Timorese played multiple roles either simultaneously or at different times, in an effort to survive (Drexler 2013: 3). To take one key example, those who voluntarily surrendered with weapons and those who collaborated with the enemy either during or after leaving the struggle are barred from the scheme (World Bank 2008: 19-21). Yet, these grounds for disqualification raise tough questions such as "how to determine the difference between "willing collaboration with the enemy" and working with the Indonesian administration while supporting the resistance clandestinely?' Measuring the extent to which surrender with a gun was 'voluntary' is also inherently problematic (World Bank 2008: 21). ${ }^{15}$

190 


\section{Veterans and politics}

The fact that these distinctions are deemed important at all reveals much about the perceived necessity of maintaining the resistance narrative, with its underpinning myth of a national liberation struggle that was unified, highly structured and organised against a common (external) enemy. In other words, the existence of these distinctions highlights the degree to which current imaginings of national identity rest on the continuing portrayal of the resistance as an armed struggle by East Timorese nationalists against colonial domination. This results directly in the occlusion of what was in reality a far more complicated process that involved multiple actors and interests and shifting roles (cf Metsola 2010: 609). Because maintaining the resistance narrative requires individuals to squeeze the complexities of their experiences into the narrow administrative categories of the scheme, ongoing forms of challenge and contestation regarding 'errors' in the veterans' database and claims of false veteran-hood are perhaps inevitable.

\section{Negotiating veteran identity}

Attempts to resolve the veterans' problem are further complicated by the way the veterans' criteria are actively negotiated 'on the ground' through the registration and data verification processes. This dimension of the scheme is illustrated compellingly by Kate Roll's extensive empirical research. Roll found that, despite the existence of firm criteria of eligibility, the process of registration and verification is far messier and more negotiable in practice. She documents how the CHSRR commissioners who oversee these processes (most of whom had been selected based on their senior roles within resistance structures) act as literal 'gatekeepers' (Roll 2014a: 96). Specifically, commissioners use their positions to extract rents (e.g. demanding payments to be registered); include ineligible individuals due to pre-existing family ties; exaggerate the service records of family members or close associates; reduce or exclude the service records of some individuals due to personal disputes; and use personal connections to those in power to fast-track payments or resolve issues with registration. Roll also found commissioners to be quite open about the ways in which they 'modify' eligibility criteria to 'recognize special service and incorporate members of the clandestine front' where they deemed this necessary (Roll 2014a: 196-199, 2014b: 487).

Roll's insights enable a deeper appreciation of the negotiated nature of the veterans' scheme. They help to shed light, for instance, on why some individuals and groups have been successful in pushing for their inclusion within the scheme even if they do not meet the criteria. A key example of this can be seen in the efforts of the 12 November committee - an organisation that represents over 2,000 survivors of the Santa Cruz massacre of 1992 (ICG 2011: 8) - to argue for the recognition of those who had been involved in the initial demonstration that sparked the massacre. At the time of the 20th anniversary of Santa Cruz, the secretary of state for veterans' affairs explained that the 1991 organisers 'could only count their involvement as one day of service' (ICG 2011: 8). Yet, because of its political influence and its close links to the political elite, the committee has successfully advocated for their inclusion in the scheme on the grounds of 'special service' (Roll 2014a: 201-202). ${ }^{16}$

The example of the 12 November committee highlights the reality that whilst there is some room for negotiation around the criteria for exclusion/inclusion within the scheme, not all Timorese have the same capacity to negotiate. Money or personal connections (through kin or resistance networks) to those in power are key. In this sense, CHSRR commissioners might be understood as bolstering their own power by mediating exchanges between 'little men' and political leaders in a dynamic that some commentators describe as clientelism (Scambary 2015: 287). All of this suggests that the veterans' scheme is fostering a 
vision of citizenship that differs sharply from its (idealised) liberal conceptualisation in which rights-holding citizens are portrayed as participating equally in a polity. By reinforcing the idea that the state is a source of benefits and resources that those with the right connections may tap into, the scheme underscores the continuing relevance of resistance-era networks and patronage politics in independent Timor-Leste (Roll 2014a: 194).

\section{The boundaries of citizenship}

The veterans' scheme has not only worked to construct veteran-hood as a privileged category of citizenship, but it has also helped to construct the parameters around which many other struggles for recognition are taking place. To put this differently, the scheme (and the resistance narrative that animates it) has provided a 'frame of meaning' and a set of identity positions through which Timorese can make sense of their past experiences and make claims for legitimacy as citizens in the present (Wale 2016: 10). This positioning can be seen in the wide range of initiatives by groups that are not necessarily aimed at achieving the privileges and benefits associated with formal veteran status, but nonetheless seek to carve out a space for themselves within the resistance narrative by claiming that their contributions to the nation's liberation have hitherto been overlooked.

Examples of such efforts can be seen in the recently announced initiative of the Secretary of State for Youth and Sport to document the experiences of youth during the resistance. This initiative follows on from the nationwide project initiated by the Popular Organisation of East Timorese Women (Organizacao Popular de Mulher Timor-OPMT) in 2010, to document women's diverse roles in the resistance. The OPMT project, which undertook interviews with hundreds of East Timorese women around the country, sought to challenge the militarised, masculine emphasis of the resistance narrative by drawing attention to women's under-recognised roles in the struggle and to the importance of everyday forms of resistance in the sphere of the family, the community and the church. In this sense, it subtly attempts to broaden the meanings of heroism and sacrifice in Timor-Leste (Kent 2016).

The centrality of the resistance narrative to current imaginings of citizenship creates difficulties however, for those who are unable to claim even a lowly place within it. A clear hierarchy of the deserving, and a clear sense of insiders and outsiders, has been constructed. Evidence of this can be seen in the prevalence of accusations of 'treachery' which, from time to time, are directed at those who are perceived not to have contributed to the nation's liberation and to be unjustly benefitting from the fruits of independence. Amongst those targeted are members of the extensive East Timorese diaspora (who are said to have led easy lives abroad and then returned to claim good jobs following the nation's independence) and those who had supported Timor-Leste's integration with Indonesia. ${ }^{17}$

Questions of legitimacy also hang over younger generations of East Timorese, including activists who studied in Indonesia during the occupation and are now in their forties. Whilst some have been able to carve out public, political roles, the formal political sphere remains dominated by an older generation of resistance leaders who continue to bemoan the 'lack of readiness among the younger generation' for political leadership whilst failing to provide opportunities for them (ICG 2011: 16; Anibal 2017). Those who are part of an even younger generation born after the referendum are continually reminded of their 'easy' lives and their need to work hard to uphold the values of their heroic predecessors. Their place near the bottom of the hierarchy of citizenship is reinforced by what Bexley refers to as a 'youth defectology' discourse that focuses on 'young people as a violent problem' (Bexley and Tchailoro 2013: 407, citing Comaroff and Comaroff 2005).

192 


\section{Veterans and politics}

One of the starkest examples of how the resistance narrative creates a hierarchy of the deserving can be seen in the public debates surrounding the issue of reparations. Since the 1999 referendum, human rights organisations and activists have argued that civilians who experienced human rights abuses during the Indonesian occupation should be entitled to reparations to help alleviate the suffering they endured. Their efforts to lobby for a reparations programme have, however, been vociferously opposed by political leaders and powerful veterans in the parliament who have argued that the needs of victims can only be attended too once the 'veterans question' is resolved (Kent 2016: 59). Whilst these arguments evoke a hierarchy in which the interests of former armed combatants are elevated above those of other groups in society, they are also underpinned by deeper anxieties. By promoting the idea that all Timorese who experienced human rights violations should be recognised regardless of their past roles, the concept of reparations profoundly unsettles constructions of citizenship based on contributions to the resistance. Specifically, it undercuts the common perception that those who supported integration with Indonesia are 'traitors' who do not deserve to be compensated for any harm done to them (Ottendorfer 2013: 32). It also unsettles narratives of national unity by potentially drawing unwelcome attention to the divisions in the resistance movement, and to the human rights violations committed by the resistance against those within its own ranks (Ottendorfer 2013: 32).

\section{Conclusion}

It seems clear that the veterans' scheme has emerged as a key site where questions of citizenship, belonging, identity and reward are socially mediated. The scheme has entrenched the power of elite, male, resistance figures through the development of veterans' criteria that include/exclude individuals according to their roles in the resistance and their years of service, as well as through the performance of registration and verification. This power looks set to become further entrenched following the recent passage of a new decree law that establishes a Council of National Liberation Combatants to represent veterans' interests to the government. ${ }^{18}$

What also seems clear is that, contrary to the argument made by national political leaders and international organisations that recognising veterans is necessary for national stability, veteran-hood has become a site of ongoing debate, challenge and contestation. The high stakes associated with veteran identity and the degree to which there is room for the negotiation of veteran status suggest that there is unlikely to be a definitive resolution of the kestaun veteranus in the short term.

More broadly, the veterans' scheme reinforces the centrality of the resistance narrative within current imaginings of East Timorese identity in ways that prevent the emergence of other, potentially more inclusive, visions of citizenship. This is in part because this narrative provides a frame of meaning and a set of identity positions around which other struggles for recognition are taking place. Whilst important initiatives are underway that seek greater recognition for the contributions of women and youth to the resistance, questions need to be asked about how far this narrative can be stretched and the degree to which it has the capacity to exclude those who cannot find a space within it.

\section{Notes}

1 This amounts to \$USD 105 million compared to \$USD 73 million spent the same year on health.

2 This amount could double if new veterans continue to register or the minimum wage goes up (La'o Hamutuk 2013). 
3 For instance, veterans have been the frequent recipients of contracts under infrastructure funds. In 2010-2012, contracts to veterans for projects relating to the national electrification scheme totalled \$78 million and were awarded without a tender process (Leach 2017: 213; Scambary 2015: 295).

4 Political parties and leaders frequently draw on their credentials as veterans to bolster their legitimacy. In the lead-up to the 2012 elections, for instance, the resistance credentials of two former FALINTIL commanders, Xanana Gusmão and Taur Matan Ruak, were conspicuously on display (Leach 2017: 209). Similarly in relation to the 2017 presidential elections, the fact that candidate Francisco 'Lu'olo' Guterres clearly outstripped his competitors was also at least partly a reflection of his status as a prominent guerrilla commander.

5 Reports extracted from CHSRR database. Interview with president of CHSRR, Dili, TimorLeste, 16 April 2018.

6 Law $3 / 2006$ as amended by Law 9/2009 of 29 July 2009, Article 4.

7 Law 3/2006 as amended by Law 9/2009 of 29 July 2009, Article 23 (1), 31-32

8 Law 3/2006 as amended by Law 9/2009 of 29 July 2009, Article 23 (2). This is a largely symbolic entitlement, however, as primary health care and education are supposedly free for all Timorese citizens.

9 Decree Law 8/2009 of 15 January 2008. In 2010 and 2011, a total of 250 scholarships were available to a total amount of USD 152,250 and USD 169,900 respectively.

10 See Law 3/2006 prior to its amendment in English. Available at http://www.unmit.org/legal/ RDTL-Law/RDTL-Laws/Law-2006-03.pdf (accessed 10 June 2012).

11 'In 2010, $41 \%$ of the population lived on less than US $\$ 38$ per month. The veterans' scheme also dwarfs the small amounts of social assistance available to other groups, including the elderly and female-headed households (Kent and Wallis 2014).

12 Clandestinos, including former members of the youth clandestine front, have protested the unfairness of a scheme that has seen a disproportionate amount of benefits flowing to former guerrillas who were dependent upon their support for their survival (e.g. see Gusmão 2016b).

13 Presidential Decree 56/2006 of 5 December 2006.

14 Interview with staff member of CHSRR, Dili, Timor-Leste, 16 April 2018

15 The World Bank report notes that this criterion was in practice dropped because of the large number of combatants who surrendered with guns in the late 1970s and later rejoined the resistance (World Bank 2008: 21).

16 Further evidence of the rise of Santa Cruz survivors within the 'heroic hierarchy' can be seen in the public prominence that is now given to marking this event; 12 November is now a national public holiday and is celebrated throughout Timor-Leste as National Youth Day. The TimorLeste Parliament has pledged $\$ 8$ million for an official memorial to the event (Rothschild 2015: 98), the first stone of which was laid at the 2016 commemorations.

17 In late 2012, for instance, the F-FDTL chief Major General Lere 'promised to modify the army recruitment system to prohibit recruitment of the children of pro-Indonesian supporters' (Leach 2017: 212). Discourses of treachery have gained new meanings in recent discussions of revising the Lei Pensaun Vitalisia (Law on Subsistence Pensions), which provides lifetime pensions to parliamentarians. Arguments are put that the provision of pensions to parliamentarians (some of whom have only served one 5-year term) amounts to a form of treachery against those who fought for independence (e.g. Farga, Raimundo et al. 2016). Suggestions have also been made that the pensions are unfairly benefitting some parliamentarians who had been traitors in the past.

18 See Decree Law No 7, 28 March 2018.

\section{References}

Anibal Joao. (2017) 'Veteranus Seidauk Konfia Jerasaun Foun Kaer Ukun' (Veterans are not yet confident that the young generation can take the lead), Suara Timor Lorosae, 15 February 2017, Available athttp://suara-timor-lorosae.com/veteranus-seidauk-konfia-jerasaun-foun-kaer-ukun/ (accessed 28 November 2017).

Bexley Angie and Nuno Rodrigues Tchailoro. (2013) 'Consuming Youth: Timorese in the Resistance Against Indonesian Occupation', The Asia Pacific Journal of Anthropology, 14(5): 405-422.

Comaroff John and Jean Comaroff. (2005) 'Reflections on Youth from the Past to the Postcolony', In Makers and Breakers: Children and Youth in Postcolonial Africa, A Honwana, F. De Boeck and J. Currey (eds), pp. 31-52, Oxford: Africa World Press. 


\section{Veterans and politics}

de Vries Hugo and Nikkie Wiegink. (2011) 'Breaking Up and Going Home? Contesting Two Assumptions in the Demobilization and Reintegration of Former Combatants', International Peacekeeping, 18(1): 38-51.

Drexler Elizabeth. (2013) 'Fatal Knowledges: The Social and Political Legacies of Collaboration and Betrayal in Timor-Leste', International Journal of Transitional Justice, 7(1): 74-94.

Farga Raimundo S., Timotio Gusmão and Carmen Ximenes. (2016) 'Aprova Osan PV, Trai Heroi $\mathrm{Ne}$ 'be Mate Ba Independensia' (Approving money for pension vitalisia is treachery against those who died for independence), Suara Timor Lorosae, 2 November 2016.

Fundasaun Mahein. (2015) 'The Complex Problem of Veterans in Timor-Leste', Press Release, 16 December 2015. Available at www.fundasaunmahein.org/2015/12/16/the-complex-problem-ofveterans-in-timor-leste/ (accessed 28 November 2017).

Gusmão Timotio. (2016a) 'Rezolve Problema Veteranu, Tenki Ativa Organizasaun Rezistensia' (To resolve the veterans problem there is a need to reactivate resistance organisations), Suara Timor Lorosae, 9 January 2017. Available at http://suara-timor-lorosae.com/rezolve-problema-veteranutenki-ativa-organizasaun-rezistensia (accessed 28 November 2017).

Gusmão Timotio. (2016b) 'La Hetan Pensaun, Governu Izola Joven Klandestina Tempu Funu' (Without pensions, the government isolates the clandestine youth from the conflict time), Suara Timor Lorosae, 21 October 2016. Available at http://suara-timor-lorosae.com/la-hetan-pensaungovernu-izola-joven-klandestina-tempu-funu/ (accessed 28 November 2017).

ICG (International Crisis Group). (2011) 'Timor-Leste's Veterans: An Unfinished Struggle? Asia Briefing No. 129, Dili, Jakarta, Brussels: International Crisis Group.

Isin Engin F. (2008) 'Theorizing Acts of Citizenship', In Acts of Citizenship, Engin F. Isin and Greg M. Nielsen (eds), pp. 15-43, London: Zed Books.

Jeffrey, Alex and Jakala, Michaelina. (2015) 'Using Courts to Build States: The Competing Spaces of Citizenship in Transitional Justice Programmes', Political Geography, 47: 43-52.

Kammen Douglas. (2009) 'Fragments of Utopia: Popular Yearnings in East Timor', Journal of Southeast Asian Studies, 4(2): 385-408

Kent Lia. (2006) Independent Evaluation of the CAQR, Dili: The World Bank

Kent Lia. (2016) 'After the Truth Commission: Gender and Citizenship in Timor-Leste', Human Rights Review, 17(1): 51-70.

Kent Lia and Joanne Wallis. (2014) 'Timor-Leste's Veterans' Pensions Scheme: Who Are the Beneficiaries and Who Is Missing Out?' SSGM In-Brief 2014/3: 1-2.

Kent Lia and Naomi Kinsella. (2015) 'A Luta Kontinua (The Struggle Continues): The Marginalization of East Timorese Women within the Veterans' Valorization Scheme', International Feminist Journal of Politics, 17(3): 473-494.

Kings College London. (2003) A Review of Peace Operations: A Case for Change, East Timor. London: Kings College.

La'o Hamutuk. (2013) Presentation: The National Impact of Benefits for Former Combatants, Available at www.laohamutuk.org/econ/pension/VetPension6Mar2013en.pdf (accessed 28 November 2017).

La'o Hamtuk. (2017) General State Budget 2017. www.laohamutuk.org/econ/OGE17/16OGE17. htm\#docs (accessed April 2 2018).

Leach Michael. (2017) Nation-Building and National Identity in Timor-Leste. London and New York: Routledge.

Martins Vasco. (2017) 'Politics of Power and Hierarchies of Citizenship in Angola', Citizenship Studies, 21(1): 100-115

McEwen Cheryl. (2005) 'New Spaces of Citizenship? Rethinking Gendered Participation and Empowerment in South Africa', Political Geography, 24: 969-991.

Metsola Lalli. (2006) "Reintegration" of Ex-Combatants and Former Fighters: A Lens into State Formation and Citizenship in Namibia', Third World Quarterly, 27(6): 1119-1135.

Metsola Lalli. (2010) 'The Struggle Continues? The Spectre of Liberation, Memory Politics and "War Veterans" in Namibia', Development and Change, 41(4): 589-613.

Muggah Robert and Chris O’Donnell. (2015) 'Next Generation Disarmament, Demobilization and Reintegration', Stability; International Journal of Security and Disarmament, 4(1): 1-12, Available at www.stabilityjournal.org/articles/10.5334/sta.fs/ (accessed 29 November 2017).

Myrttinen Henri. (2014) 'Claiming the Dead, Defining the Nation: Contested Narratives of the Independence Struggle in Post-Conflict Timor-Leste', In Governing the Dead: Sovereignty and the Politics of Dead Bodies, F. Stepputat (ed.), pp. 95-113, Manchester and New York: Manchester University Press. 
Nagel Joane. (1998) 'Masculinity and Nationalism: Gender and Sexuality in the Making of Nations', Ethnic and Racial Studies, 21(2): 242-269.

Niner Sara. (2013) 'Bisoi: A Veteran of Timor-Leste's Independence Movement', In Women in Southeast Asian Nationalist Movements, S. Blackburn and H. Ting (eds), pp. 226-249, Singapore: NUS Press.

Ong Aihwa. (2003) 'Buddha Is Hiding: Refugees, Citizenship and the New America', California Series in Public Anthropology. Berkeley: University of California Press.

Ottendorfer Eva. (2013) 'Contesting International Norms of Transitional Justice: The Case of Timor-Leste', International Journal of Conflict and Violence, 7(1): 23-35.

Pouligny Béatrice. (2004) The Politics and Anti-Politics of Contemporary "Disarmament, Demobilization and Reintegration" Programs. Geneva: Programme for Strategic and International Security Studies. Available at www.operationspaix.net/DATA/DOCUMENT/5772 v $\sim$ Les_anciens_combattants_d_aujourd_ hui__Desarmement_Demobilisation_et_Reinsertion.pdf (accessed 28 November 2017).

RDTL (Democratic Republic of Timor-Leste). (2002) The Constitution of the Democratic Republic of Timor-Leste. Dili: Constituent Assembly of Timor-Leste.

Roll Kate. (2014a) Inventing the Veteran, Imagining the State: Post-Conflict Reintegration and State Consolidation in Timor-Leste, 1999-2012, Unpublished PhD thesis, Oxford: Oxford University.

Roll, Kate. (2014b) 'Encountering Resistance: Qualitative Insights from the Quantitative Sampling of Ex-Combatants in Timor-Leste', PS: Political Science and Politics, 47(2): 485-489.

Rothschild Amy. (2015) 'Democratization of Perpetration: Human Rights, Transitional Justice and Memories of Resistance in Post-Conflict Timor-Leste', Conflict and Society: Advances in Research, 1: $92-108$.

Scambary James. (2015) 'In Search of White Elephants: The Political Economy of Resource Income Expenditure in East Timor', Critical Asian Studies, 47(2): 283-308.

Sriram Chandra Lekha and Johanna Herman. (2009) 'DDR and Transitional Justice: Bridging the Divide? Conflict, Security and Development, 9(4): 455-474.

Wale Kim. (2016) South Africa's Struggle to Remember: Contested Memories of Squatter Resistance in the Western Cape. Abingdon: Taylor and Francis

World Bank. (2008) 'Defining Heroes: Key Lessons from the Creation of Veterans Policy in TimorLeste', Report No 45458-TP, Washington: The World Bank. 